\title{
A functional bioassay to determine the activity of anti-VEGF antibody therapy in blood of patients with cancer
}

\author{
Madelon Q Wentink ${ }^{1}$, Henk J Broxterman ${ }^{1}$, Siu W Lam ${ }^{1}$, Epie Boven ${ }^{1}$, Maudy Walraven ${ }^{2}$, Arjan W Griffioen ${ }^{1}$, \\ Roberto Pili ${ }^{3}$, Hans J van der Vliet ${ }^{1}$, Tanja D de Gruijl ${ }^{1}$ and Henk M W Verheul ${ }^{\star}, 1$ \\ ${ }^{1}$ Department of Medical Oncology, VU University Medical Center, Amsterdam, The Netherlands; ${ }^{2}$ Department of Medical \\ Oncology, University Medical Center, Utrecht, The Netherlands and ${ }^{3}$ Department of Hematology/Oncology, Indiana University, \\ Indianapolis, Indiana
}

Background: Only a small proportion of patients respond to anti-VEGF therapy, pressing the need for a reliable biomarker that can identify patients who will benefit. We studied the biological activity of anti-VEGF antibodies in patients' blood during antiVEGF therapy by using the Ba/F3-VEGFR2 cell line, which is dependent on VEGF for its growth.

Methods: Serum samples from 22 patients with cancer before and during treatment with bevacizumab were tested for their effect on proliferation of Ba/F3-VEGFR2 cells. Vascular endothelial growth factor as well as bevacizumab concentrations in serum samples from these patients were determined by enzyme linked immunosorbent assay (ELISA).

Results: The hVEGF-driven cell proliferation was effectively blocked by bevacizumab (IC $503.7 \mu \mathrm{g} \mathrm{ml}^{-1}$; 95\% Cl 1.7-8.3 $\mu \mathrm{g} \mathrm{ml}^{-1}$ ). Cell proliferation was significantly reduced when patients' serum during treatment with bevacizumab was added (22-103\% inhibition compared with pre-treatment). Although bevacizumab levels were not related, on-treatment serum VEGF levels were correlated with Ba/F3-VEGFR2 cell proliferation.

Conclusions: We found that the neutralising effect of anti-VEGF antibody therapy on the biological activity of circulating VEGF can be accurately determined with a Ba/F3-VEGFR2 bioassay. The value of this bioassay to predict clinical benefit of anti-VEGF antibody therapy needs further clinical evaluation in a larger randomised cohort.

\begin{abstract}
Angiogenesis is important for tumour growth and metastasis. The most abundant and well-described angiogenic growth factor, vascular endothelial growth factor (VEGF), has been thoroughly investigated in the clinic as a therapeutic target to inhibit angiogenesis. The anti-VEGF monoclonal antibody bevacizumab is approved for use in combination with different chemotherapy regimens as a treatment for several advanced solid malignancies (Ferrara and Adamis, 2016; Jayson et al, 2016), whereas the fusion protein VEGF-trap is approved for the treatment of metastatic colorectal cancer (mCRC; Ferrara and Adamis, 2016; Jayson et al, 2016). For these anti-angiogenic therapeutics, there is a major lack of knowledge on biological determinants that can predict clinical
\end{abstract}

benefit in patients with cancer (Jayson et al, 2016). Most research focused on circulating proteins (Pommier et al, 2014), vascular changes monitored by DCE-MRI (Mehta et al, 2011; Guo et al, 2015) or immunohistochemistry (IHC; Giatromanolaki et al, 2012) as well as clinical parameters (Nakaya et al, 2016), as potential biomarkers for response.

Vascular endothelial growth factor is widely expressed throughout the human body and circulates as an angiogenic factor in blood predominantly carried by platelets (Verheul et al, 1997). Neutralisation of platelet VEGF by bevacizumab occurs within $8 \mathrm{~h}$ following administration and this neutralisation inhibits platelet-induced endothelial cell proliferation (Verheul et al, 2007). Other cell types

*Correspondence: Professor HMW Verheul; E-mail: h.verheul@vumc.nl 
which secrete and express VEGF include fibroblasts (Dong et al, 2004), leucocytes, tumour cells and skeletal muscle cells (Kut et al, 2007). Although the VEGF concentration in tumour tissue is considerably higher than in the blood compartment, the total quantity of VEGF in a tumour is relatively low compared with total VEGF available in man. It appears that skeletal muscle tissue is actually the main source of VEGF in the human body (Kut et al, 2007). In the context of anti-angiogenic therapy, neutralisation of tumour-derived VEGF as well as VEGF from normal tissue may be equally important. In that respect, it might be challenging to eliminate the relatively small amount of VEGF present in the tumour microenvironment completely considering the large amount of VEGF derived from other body compartments, which may need to be neutralised as well.

Treatment with bevacizumab has shown to reduce free VEGF levels in serum and plasma as determined by ELISA (Del et al, 2010; Loupakis et al, 2011; Hayashi et al, 2014). This indicates that the growth factor is indeed neutralised in blood, which consequently prevents the dimerisation and activation of VEGFR2 expressed on endothelial cells. In contrast, there are studies reporting increased circulating free VEGF levels after starting bevacizumab treatment (Baar et al, 2009; Willett et al, 2009). This could possibly be due to the exchange of VEGF, bevacizumab and the bevacizumab-VEGF immune complex between tumour tissue and the circulation (Stefanini et al, 2010), increased synthesis or decreased clearance of VEGF in the presence of bevacizumab (Hsei et al, 2002). Whether anti-VEGF therapy also depletes VEGF in the tumour microenvironment is unknown. Several models indicate that free VEGF in the tumour itself is indeed significantly reduced upon bevacizumab treatment (Stefanini et al, 2010; Finley and Popel, 2013), though experimental data in patients with cancer confirming these data are lacking. Recent reports indicated that the tumour uptake of PET-tracer labelled bevacizumab is significantly reduced after anti-angiogenic treatment in patients with melanoma or renal cell cancer, indirectly suggesting that the expression of the drug target (VEGF) in the tumour microenvironment is reduced (Nagengast et al, 2011; Oosting et al, 2015). However, a decreased tumour uptake of PET-tracer labelled bevacizumab could also be due to reduced tumour penetration from anti-angiogenic treatment.

If related to their efficacy, measuring the degree of VEGF blockade in the circulation may represent a useful readout for potential efficacy of bevacizumab or VEGF-trap. There is no consensus on the use of serum or plasma to determine meaningful VEGF levels, because serum concentrations are mainly comprised of VEGF released by activated platelets whereas plasma only constitutes free circulating VEGF. Inadequate plasma preparation can also lead to platelet activation, which results in falsely elevated plasma VEGF levels (Webb et al, 1998; Brookes et al, 2010). The value of baseline serum or plasma VEGF levels as a prognostic factor for outcome in patients with cancer has been reported, though this may largely be due to its direct correlation with the number of circulating platelets (Verheul et al, 1997; Pinedo et al, 1998; George et al, 2000; Verheul and Pinedo, 2007). It has also been shown that platelet VEGF content is higher in patients with cancer compared with healthy controls (Niers et al, 2011; Peterson et al, 2012), possibly through an increased tendency of ex vivo platelet activation (Niers et al, 2011). The results on circulating VEGF as predictive biomarker for response to treatment are even more inconsistent (Hegde et al, 2013). Overall, these data indicate that VEGF neutralisation in blood as determined by ELISA may not reflect the anti-angiogenic and anti-tumour efficacy of antiVEGF treatment.

During anti-VEGF therapy, such as bevacizumab, a new equilibrium emerges between free VEGF, bevacizumab and VEGFR2 and either bound VEGF to bevacizumab and bound VEGF to cellular or free circulating VEGFRs in the different body compartments (Stefanini et al, 2010; Finley et al, 2011; Finley and Popel, 2013). In case of effective neutralisation this balance would shift towards more VEGF-bevacizumab complexes resulting in reduced levels of free VEGF and inhibition of VEGFR2-mediated angiogenesis. We reasoned that a direct test evaluating the competitive action of bevacizumab in inhibiting the binding of VEGF to VEGFR2 in the patients' blood-endothelium interface during anti-VEGF therapy could serve as a predictive biomarker for response. Here we describe the development of such a bioassay. In this bioassay the inhibition of VEGF-dependent cell proliferation by patients' serum is assessed using the Ba/F3-VEGFR2 cell line, which is a murine pre-B lymphocyte cell line engineered to become dependent on VEGF for proliferation and survival (Figure $1 \mathrm{~A}$ and $\mathrm{B}$ ). Cell proliferation assays with the $\mathrm{Ba} / \mathrm{F} 3$ VEGFR2 cell line were performed to explore the VEGF blocking activity of bevacizumab or patients' serum before and during bevacizumab therapy (Figure $1 \mathrm{C}$ and D). We hypothesised that the inhibition of VEGF-induced cell proliferation by the addition of patients' on-treatment serum is related to the anti-angiogenic potential of bevacizumab in the individual patient, and could therefore be of use for prediction of clinical efficacy.

\section{MATERIALS AND METHODS}

Ba/F3-VEGFR2 cell culture. The Ba/F3-VEGFR2 cells were a kind gift from K. Alitalo (Helsinki, Finland) and were licensed by the Ludwig Institute for Cancer Research, New York, NY. The generation of these cells is described elsewhere (Stacker et al, 1999; Makinen et al, 2001). In brief, parental mIL-3R $+\mathrm{Ba} / \mathrm{F} 3$ cells were transfected with a receptor chimera consisting of the extracellular domain of VEGFR2 and the transmembrane and cytoplasmic domain of mouse erythropoietin receptor (mEpoR). This resulted in a cell line dependent on human VEGF (hVEGF; R\&D Systems, Minneapolis, USA) or mouse IL-3 (mIL3; R\&D systems) for proliferation and survival. A graphical representation of these cells is shown in Figure 1. Ba/F3-VEGFR2 cells were maintained as suspension cultures in DMEM (Lonza, Verviers, Belgium) supplemented with $10 \%$ heat-inactivated foetal bovine serum (FBS; BioWest SAS, Nuaillé, France), Penicillin-Streptomycin (Lonza), L-glutamine (2 mM; Scharlab S.L., Barcelona, Spain), mIL3 $\left(4 \mathrm{ng} \mathrm{ml}^{-1}\right)$, zeocin $\left(500 \mu \mathrm{g} \mathrm{ml}^{-1}\right.$; Invitrogen, California, USA) in an atmosphere of $5 \% \mathrm{CO}_{2}$ at $37^{\circ} \mathrm{C}$.

Patient samples. A total of 44 serum samples from 22 patients were included in this study. From eight patients (nr 1-8) with advanced solid tumours of various types who received bevacizumab every 2 weeks as monotherapy or in combination with chemotherapy as standard therapy, serum samples were obtained in the context of a study evaluating the pharmacodynamics of antiVEGF therapy (Verheul et al, 2008). Sixteen serum samples obtained pre-treatment $(\mathrm{C} 1)$ and before the second bevacizumab administration ( 2 weeks after start of treatment) were used for the purpose of this particular study. In addition, 28 serum samples were obtained from 14 patients (nr 9-22) with locally recurrent or metastatic breast cancer participating in a phase II clinical trial in which bevacizumab ( $10 \mathrm{mg} \mathrm{kg}^{-1}$ every 2 weeks) was given in combination with paclitaxel (Lam et al, 2014). Serum samples were obtained pre-treatment $(\mathrm{C} 1)$ and before the third bevacizumab administration (4 weeks after start of treatment). For both studies, approval was given by the local ethical committee and all patients provided written informed consent before study entry.

Ba/F3-VEGFR2 cell proliferation assay. A volume of $50 \mu \mathrm{l}$ complete medium (DMEM, supplemented with 10\% heat-inactivated FBS and antibiotics) containing hVEGF $\left(1.25 \mathrm{ng} \mathrm{ml}^{-1}\right)$ or mIL3 $\left(4 \mathrm{ng} \mathrm{ml}^{-1}\right)$ was pre-incubated with or without bevacizumab (Avastin; Roche, Welwyn Garden City, UK) and plated in a 

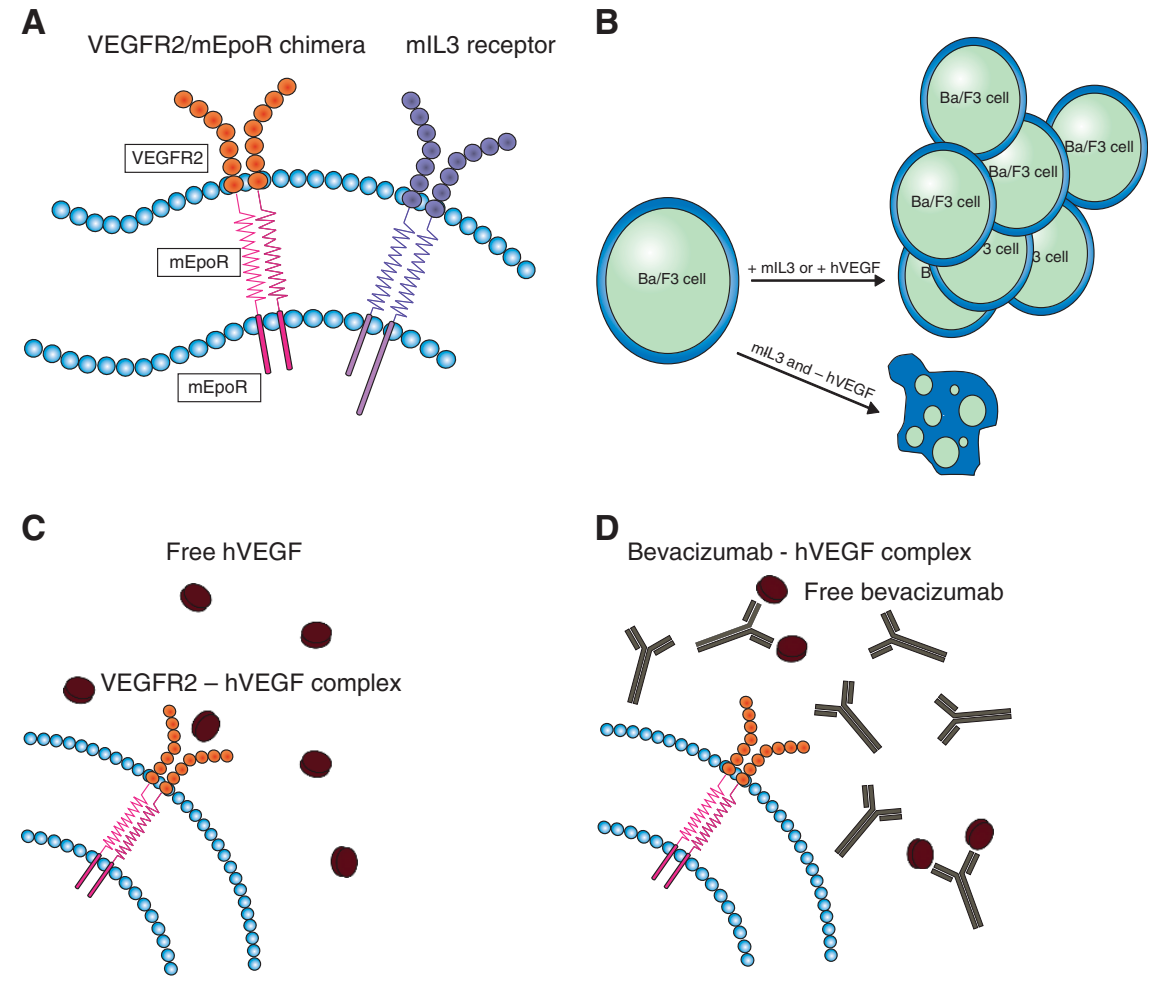

Figure 1. Structure of Ba/F3-VEGFR2 cells. Ba/F3-VEGFR2 cells exhibit two critical receptors; the VEGFR2/mEpoR chimera (consisting of the extracellular domain of VEGFR2 fused to the transmembrane and cytoplasmic domain of mEpoR) and the mIL3 receptor (A). Ba/F3-VEGFR2 proliferate and survive on mIL3 or hVEGF. When grown in medium devoid of these growth factors the cells stop proliferating (B). Before start of treatment VEGF is able to bind VEGFR2 (C). Upon start of treatment with bevacizumab a new equilibrium arises of free VEGF, free bevacizumab and VEGF bound to bevacizumab (D).

96-wells plate for one hour at $37^{\circ} \mathrm{C}$. In other experiments, complete medium containing hVEGF $\left(1.25 \mathrm{ng} \mathrm{ml}^{-1}\right)$ was preincubated with human Ig or patients' serum (either pre-treatment or on-treatment). Titrations determining the optimal serum dilution to be used in the bioassay were performed using sera of healthy volunteers. It was found that $1: 20$ dilution was the lowest dilution that did not result in unspecific cell proliferation inhibition (data not shown). Consequently, patients' serum was added in a dilution of $1: 20$ in complete medium. Before adding, $\mathrm{Ba} / \mathrm{F} 3-\mathrm{VEGFR} 2$ cells were washed five times in complete medium to remove residual mIL3. After washing, $50 \mu \mathrm{l}$ complete medium containing $10000 \mathrm{Ba} / \mathrm{F} 3$-VEGFR2 cells was added to the 96-wells plate. The cells were incubated in a humidified atmosphere of $5 \%$ $\mathrm{CO}_{2}$ for $72 \mathrm{~h}$. Cell proliferation was quantified by the addition of $10 \mu \mathrm{l}$ WST-1 (Roche Applied Science, Mannheim, Germany) for 90 min. Absorbance was measured with a Tecan Spectrafluor plate reader at an optical density (OD) value of $450 \mathrm{~nm}$ and a reference wavelength of $600 \mathrm{~nm}$. The cell proliferation of hVEGF- or mIL3treated cells was calculated as percentage of the proliferation with hVEGF $1.25 \mathrm{ng} \mathrm{ml}^{-1}$ or mIL3 $4 \mathrm{ng} \mathrm{ml}^{-1}$ treated cells, respectively. For Figure $3 \mathrm{~A}$, cell proliferation when incubated with patients' sera (C1 or on-treatment) was calculated as percentage of the proliferation with hVEGF $1.25 \mathrm{ng} \mathrm{ml}^{-1}$. For Figure $3 \mathrm{~B}-\mathrm{E}$, the inhibition of cell proliferation when incubated with on-treatment patients' serum was calculated by the following formula: $100-$ (cell proliferation using on-treatment serum/cell proliferation using $\mathrm{C} 1$ serum $) \times 100 \%$. All samples were assayed in triplicates and in at least three independent experiments.

Vascular endothelial growth factor and bevacizumab measurements using ELISA. Pre-treatment (C1) and on-treatment serum hVEGF concentrations were measured in duplicate by sandwich ELISA (R\&D systems) according to the manufacturers' directions.
Human vascular endothelial growth factor concentrations were corrected for platelet counts and expressed as $\mathrm{pg} \mathrm{ml}^{-1} / 1 \times 10^{6}$ platelets. Human vascular endothelial growth factor neutralisation was calculated using the following formula: $100-$ (platelet corrected on-treatment hVEGF concentration/platelet-corrected C1 hVEGF concentration) $\times 100 \%$. Serum bevacizumab concentrations were determined in duplicate using an indirect ELISA in which recombinant carrier-free hVEGF $\left(1 \mu \mathrm{g} \mathrm{ml}^{-1}\right.$; PeproTech, London, UK) was used as capture antigen and a rabbit antibody to human IgG conjugated to horseradish peroxidase (HRP) (162.5 $\mu \mathrm{g} \mathrm{ml}^{-1}$; DakoCytomation, Glostrup, Denmark) as detection antibody. HRP activity was detected by incubation with $3,3^{\prime}, 5,5^{\prime}$-Tetramethylbenzidine (TMB; R\&D systems). The reaction was stopped by the addition of $2 \mathrm{~N} \mathrm{H}_{2} \mathrm{SO}_{4}$. The absorbance was measured with a Tecan Spectrafluor plate reader at an OD value of $450 \mathrm{~nm}$ and a reference wavelength of $540 \mathrm{~nm}$. Because of the excess of bevacizumab molecules compared with hVEGF in serum, we reasoned that the competitive effects of circulating hVEGF will be extremely small and thus will not majorly affect the bevacizumab concentrations measured in serum. We showed that circulating hVEGF (at a clinically relevant concentration of $1000 \mathrm{pg} \mathrm{ml}^{-1}$ ) did not significantly reduce the binding of immobilised hVEGF to bevacizumab in ELISA (data not shown).

Statistical analysis. One-way ANOVA with Dunnett's post test was performed to discriminate differences in cell proliferation relative to negative control (VEGF 0 or mIL3 0) or VEGF $1.25 \mathrm{ng} \mathrm{ml}^{-1}$. Spearman's correlation test was employed to evaluate the relationship between inhibition of Ba/F3-VEGFR2 cell proliferation and bevacizumab or hVEGF concentration in serum. Two-tailed $P$-values $<0.05$ were considered statistically significant and indicated with asterisks $\left({ }^{*} P \leqslant 0.05,{ }^{*} P \leqslant 0.01\right.$, $\left.{ }^{* * *} P \leqslant 0.001,{ }^{* * * *} P \leqslant 0.001\right)$. Statistical analyses were performed 
using GraphPad Prism version 5.00 for Windows, GraphPad Software, La Jolla California USA.

\section{RESULTS}

Growth stimulatory activity of hVEGF and mIL3. At first the optimal conditions for the proliferation assays were assessed. Human vascular endothelial growth factor and mIL3 stimulated $\mathrm{Ba} / \mathrm{F} 3-\mathrm{VEGFR} 2$ cell proliferation in a dose-dependent manner (Figure 2A and B). mIL3 stimulated cell proliferation when added in concentrations over $2 \mathrm{ng} \mathrm{ml}^{-1}$ compared with culture without mIL3 $(P \leqslant 0.05)$. When hVEGF was added in concentrations over $0.5 \mathrm{ng} \mathrm{ml}^{-1}$, cell proliferation was significantly increased compared with culture without VEGF $(P \leqslant 0.05)$. A clinically relevant hVEGF concentration of $1.25 \mathrm{ng} \mathrm{ml}^{-1}$ was chosen to study the effects of VEGF inhibition by bevacizumab.

Growth inhibitory activity of bevacizumab. Without the addition of hVEGF (at $1.25 \mathrm{ng} \mathrm{ml}^{-1}$ ), Ba/F3-VEGFR2 cell proliferation was reduced by $83 \%$ (s.d.) $\pm 12 \%$ ) compared with cell proliferation induced by hVEGF $1.25 \mathrm{ng} \mathrm{ml}^{-1}$ (Figure 2C). Growth stimulatory activity of hVEGF was effectively blocked by bevacizumab in a dose-dependent manner (Figure 2C). At a bevacizumab dose of $3.7 \mu \mathrm{g} \mathrm{ml}^{-1}$ (95\% CI, $\left.1.7-8.3 \mu \mathrm{g} \mathrm{ml}^{-1}\right)$ cell proliferation was reduced by $50 \%$ as compared with the condition without any bevacizumab added to hVEGF $1.25 \mathrm{ng} \mathrm{ml}^{-1}$. Non-specific human IgG did not inhibit the growth stimulatory activity of hVEGF at a comparable dose at which bevacizumab did block Ba/F3-VEGFR2 cell proliferation, that is, $100 \mu \mathrm{g} \mathrm{ml}^{-1}$ (Figure 2C). Moreover, bevacizumab did not interfere with the growth stimulatory activity of mIL3 over a dose range in which effective hVEGF blocking was observed, showing the blocking effect to be specific (Figure 2D).

hVEGF and bevacizumab concentrations in clinical samples. To establish the performance of the bioassay with patient samples, pre- and on-treatment serum samples, obtained from 22 patients who received bevacizumab within the context of two clinical studies, were used. First, hVEGF and bevacizumab concentrations were determined in these sera (Table 1 for patients 1-8 and Table 2 for patients 9-22). The mean serum hVEGF concentration of patients 1-8 before start of bevacizumab treatment was $631 \mathrm{pg} \mathrm{ml}^{-1}$ (s.d. $\pm 945 \mathrm{pg} \mathrm{ml}^{-1}$ ) and decreased to $58 \mathrm{pg} \mathrm{ml}^{-1}$ (s.d. $\pm 19 \mathrm{pg} \mathrm{ml}^{-1}$ ) after one administration of bevacizumab (Table 1). In patients 9-22 hVEGF concentrations dropped from $793 \mathrm{pg} \mathrm{ml}^{-1}$ (s.d. $\pm 836 \mathrm{pg} \mathrm{ml}^{-1}$ ) to $161 \mathrm{pg} \mathrm{ml}^{-1}$ (s.d. $\pm 56 \mathrm{pg} \mathrm{ml}^{-1}$ ) after two administrations of bevacizumab (Table 2). When corrected for platelet counts, hVEGF concentrations decreased from $1.54 \mathrm{pg} \mathrm{ml}^{-1} / 1 \times 10^{6}$ platelets (s.d. \pm 0.73 ) to $0.24 \mathrm{pg} \mathrm{ml}^{-1} / 1 \times 10^{6}$ platelets (s.d. \pm 0.14$)$ in patients $1-8$, whereas in patients

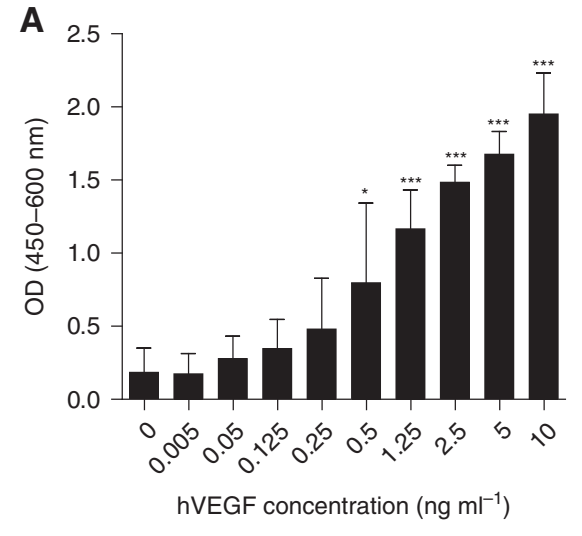

C

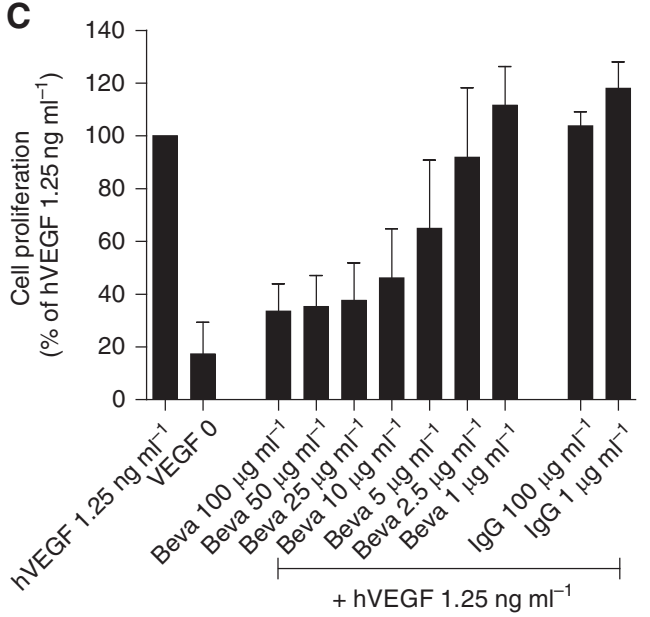

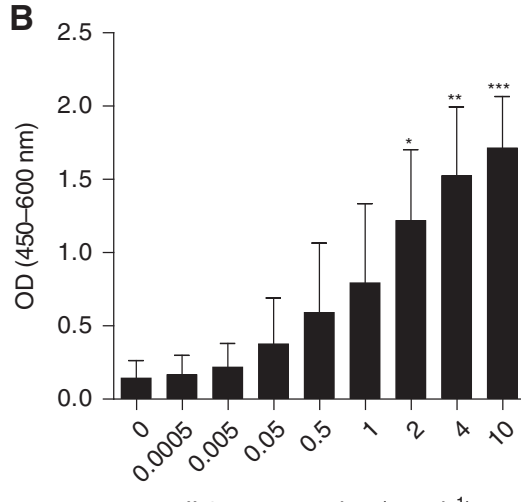

mIL3 concentration (ng ml${ }^{-1}$ )

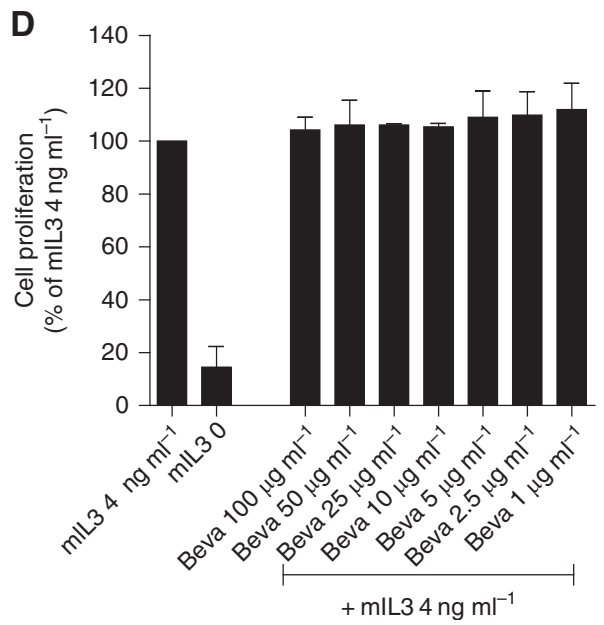

Figure 2. Ba/F3-VEGFR2 proliferate on hVEGF and mIL3 and hVEGF-driven cell proliferation can be inhibited by the addition of bevacizumab. $\mathrm{Ba} / \mathrm{F} 3-V E G F R 2$ cells proliferate dose dependently on hVEGF. Cell proliferation is calculated relative to hVEGF $10 \mathrm{ng} \mathrm{ml}^{-1}$ (A). Ba/F3-VEGFR2 cells proliferate dose dependently on mIL3. Cell proliferation is calculated relative to mIL3 $10 \mathrm{ng} \mathrm{ml}^{-1}$ (B). Co-incubation of a fixed hVEGF concentration $\left(1.25 \mathrm{ng} \mathrm{ml}^{-1}\right)$ with a titration range of bevacizumab induces a dose-dependent proliferation inhibition of Ba/F3-VEGFR2 cells, whereas total human Ig does not inhibit VEGF driven Ba/F3-VEGFR2 cell proliferation (C). Bevacizumab does not inhibit mIL3 driven Ba/F3VEGFR2 cell proliferation (D). Data are expressed as mean \pm (s.d.) of 3 independent experiments except for the experiment with total human lg in which data shown represent mean \pm s.d. of triplicate wells of 1 experiment. ${ }^{\star} P<0.05,{ }^{\star *} P<0.01,{ }^{\star * \star} P<0.001$. 
Table 1. hVEGF concentrations, platelet counts and trough bevacizumab concentrations in patients 1-8

\begin{tabular}{|c|c|c|c|c|c|c|}
\hline $\begin{array}{l}\text { Patient } \\
\text { number }\end{array}$ & Tumour type & $\begin{array}{c}\text { VEGF concentration } \\
\text { C1 }\left(\mathrm{pg} \mathrm{ml}^{-1}\right)\end{array}$ & $\begin{array}{c}\text { VEGF concentration } \\
\text { on-treatment } \\
\left(\mathrm{pg} \mathrm{ml}^{-1}\right)\end{array}$ & $\begin{array}{l}\text { Platelet count } \\
\text { C1 }\left(\times 10^{9} I^{-1}\right)\end{array}$ & $\begin{array}{l}\text { Platelet count } \\
\text { on-treatment } \\
\left(\times 10^{9} I^{-1}\right)\end{array}$ & $\begin{array}{c}\text { Bevacizumab } \\
\text { concentration } \\
\left(\mu \mathrm{g} \mathrm{ml}^{-1}\right)\end{array}$ \\
\hline 1 & Liver & 373.8 & 44.1 & 194 & 282 & 86.9 \\
\hline 3 & Neuroendocrine & 178.1 & 72.3 & 157 & 184 & 74.2 \\
\hline 4 & Ovarian & 2952.9 & 48.1 & 1157 & 1162 & 18.9 \\
\hline 7 & Breast & 200 & 91 & 246 & 223 & 41.2 \\
\hline 8 & Bladder & 388.5 & 34.5 & 446 & 445 & 24.6 \\
\hline Mean ( \pm s.d.) & & $631.0( \pm 944.6)$ & $58.2( \pm 18.7)$ & $346.8( \pm 339.9)$ & $364.4( \pm 333.4)$ & $65.0( \pm 45.3)$ \\
\hline
\end{tabular}

Table 2. hVEGF concentrations, platelet counts and trough bevacizumab concentrations in patients 9-22

\begin{tabular}{|c|c|c|c|c|c|c|}
\hline $\begin{array}{l}\text { Patient } \\
\text { number }\end{array}$ & Tumour type & $\begin{array}{c}\text { VEGF concentration } \\
\mathrm{C} 1\left(\mathrm{pg} \mathrm{ml}^{-1}\right)\end{array}$ & $\begin{array}{l}\text { VEGF concentration } \\
\text { on-treatment } \\
\left(\mathrm{pg} \mathrm{ml}^{-1}\right)\end{array}$ & $\begin{array}{l}\text { Platelet count } \\
\text { C1 }\left(\times 10^{9} I^{-1}\right)\end{array}$ & $\begin{array}{c}\text { Platelet count on- } \\
\text { treatment }\left(\times 10^{9} \mathrm{I}^{-1}\right)\end{array}$ & $\begin{array}{c}\text { Bevacizumab } \\
\text { concentration } \\
\left(\mu \mathrm{g} \mathrm{ml}^{-1}\right)\end{array}$ \\
\hline 9 & Breast & 781.2 & 169.9 & 428 & 372 & 68.3 \\
\hline 10 & Breast & 425.5 & 129 & 195 & 248 & 85.3 \\
\hline 11 & Breast & 1136.7 & 87.1 & 386 & 275 & 98.8 \\
\hline 12 & Breast & 288.5 & 171.3 & 217 & 262 & 137.9 \\
\hline 14 & Breast & 104.8 & 197.4 & 207 & 206 & 119.6 \\
\hline 15 & Breast & 218.3 & 218 & 220 & 236 & 78.5 \\
\hline 16 & Breast & 207 & 134.9 & 316 & 364 & 86.9 \\
\hline 17 & Breast & 671.9 & 167.7 & 288 & 396 & 178.6 \\
\hline 18 & Breast & 67.3 & 176.2 & 327 & 321 & 92.4 \\
\hline 22 & Breast & 1101.6 & 220.1 & 294 & 259 & 104.1 \\
\hline Mean ( \pm s.d.) & & $792.8( \pm 836.1)$ & $161.4( \pm 55.7)$ & $320.4( \pm 110.9)$ & $320.4( \pm 119.5)$ & $126.5( \pm 90.0)$ \\
\hline
\end{tabular}

9-22 concentrations reduced from $2.36 \mathrm{pg} \mathrm{ml}^{-1} / 1 \times 10^{6}$ platelets (s.d. \pm 1.81 ) to $0.61 \mathrm{pg} \mathrm{ml}^{-1} / 1 \times 10^{6}$ platelets (s.d. \pm 0.40 ; data not shown). In nearly all patients' sera hVEGF was (partly) neutralised (i.e., decreased) after one or two cycles of bevacizumab (mean \pm s.d. of patients $1-8$ by $79 \% \pm 16 \%$, in patients $9-22$ by $39 \% \pm 76 \%$ ). This was also the case for platelet-corrected hVEGF neutralisation $(80 \% \pm 16 \%$ in patients $1-8,39 \% \pm 77 \%$ in patients $9-22$ ). In two patients ( $\mathrm{nr} 14$ and 18) serum hVEGF concentrations actually increased upon bevacizumab treatment. The mean trough bevacizumab concentration in patients 1-8 was $65 \mu \mathrm{g} \mathrm{ml}^{-1}$ (s.d. $\pm 45 \mu \mathrm{g} \mathrm{ml}^{-1}$ ) and in patients 922 it was $127 \mu \mathrm{g} \mathrm{ml}^{-1}$ (s.d. $\pm 90 \mu \mathrm{g} \mathrm{ml}^{-1}$ ).

Bioassay of bevacizumab inhibitory activity in human serum. Next, the capacity of serum obtained from bevacizumab-treated patients to inhibit hVEGF-driven proliferation of Ba/F3-VEGFR2 cells was assessed. Patients' sera were diluted $1: 20$ and preincubated with $1.25 \mathrm{ng} \mathrm{ml}^{-1}$ hVEGF. After one hour, the Ba/F3VEGFR2 cells were added and $72 \mathrm{~h}$ thereafter cell proliferation was determined. As depicted in Figure 3A, patients' sera before start of bevacizumab treatment $(\mathrm{C} 1$, black bars) in general had little effect on $\mathrm{Ba} / \mathrm{F} 3-$ VEGFR2 cell proliferation. In three patients ( $\mathrm{nr} 10,16$ and 21) cell proliferation was already completely inhibited upon addition of $\mathrm{C} 1$ (i.e., pre-treatment) serum (Figure $3 \mathrm{~A}$ ) and the results of these patients were therefore excluded from further analysis. Addition of on-treatment sera was very effective in reducing Ba/F3-VEGFR2 cell proliferation (Figure $3 \mathrm{~A}$ ). In contrast to pre-treatment sera, bevacizumab containing-sera (i.e., on-treatment) were able to inhibit the hVEGF-driven proliferation of $\mathrm{Ba} / \mathrm{F} 3-\mathrm{R} 2$ cells to varying degrees in all 19 remaining patients (on average by 55\%; 95\% CI $45-65 \% ; P<0.0001$, data not shown). Due to the differences in proliferation induction by individual patient samples, pre-treatment values were set at $100 \%$ and cell proliferation inhibition using on-treatment sera were calculated accordingly. The inhibition of cell proliferation relative to pretreatment cell proliferation differed among patients ranging from 22 to $103 \%$ (mean $57 \%$ for patients $1-8$; mean $65 \%$ for patients $9-22$ ).

In Figure $3 \mathrm{~B}$ and $\mathrm{C}$ the on-treatment bevacizumab concentration in serum, as measured by ELISA, was plotted against the inhibition of $\mathrm{Ba} / \mathrm{F} 3-\mathrm{VEGFR} 2$ cell proliferation (compared with $\mathrm{C} 1$ values) induced by the addition of on-treatment patients' samples. No significant correlation between the bevacizumab concentration and the hVEGF neutralising ability in the Ba/F3-VEGFR2 cell 
culture could be detected in either patient cohort. A trend towards a statistically significant negative correlation was found between the on-treatment serum hVEGF levels (corrected for platelet counts) as determined by ELISA and the inhibition of $\mathrm{Ba} / \mathrm{F} 3-\mathrm{VEGFR} 2$ cell proliferation in patients $1-8(R=-0.7143$,
$P=0.0576$; Figure 3D), whereas in patients $9-22$ this correlation was indeed statistically significant $(R=-0.8000, P=0.0047$; Figure $3 \mathrm{E}$ ). The latter observation clearly points to a direct relationship between in vivo hVEGF neutralisation and the in vitro inhibition of hVEGF-driven Ba/F3-VEGFR2 cell proliferation.
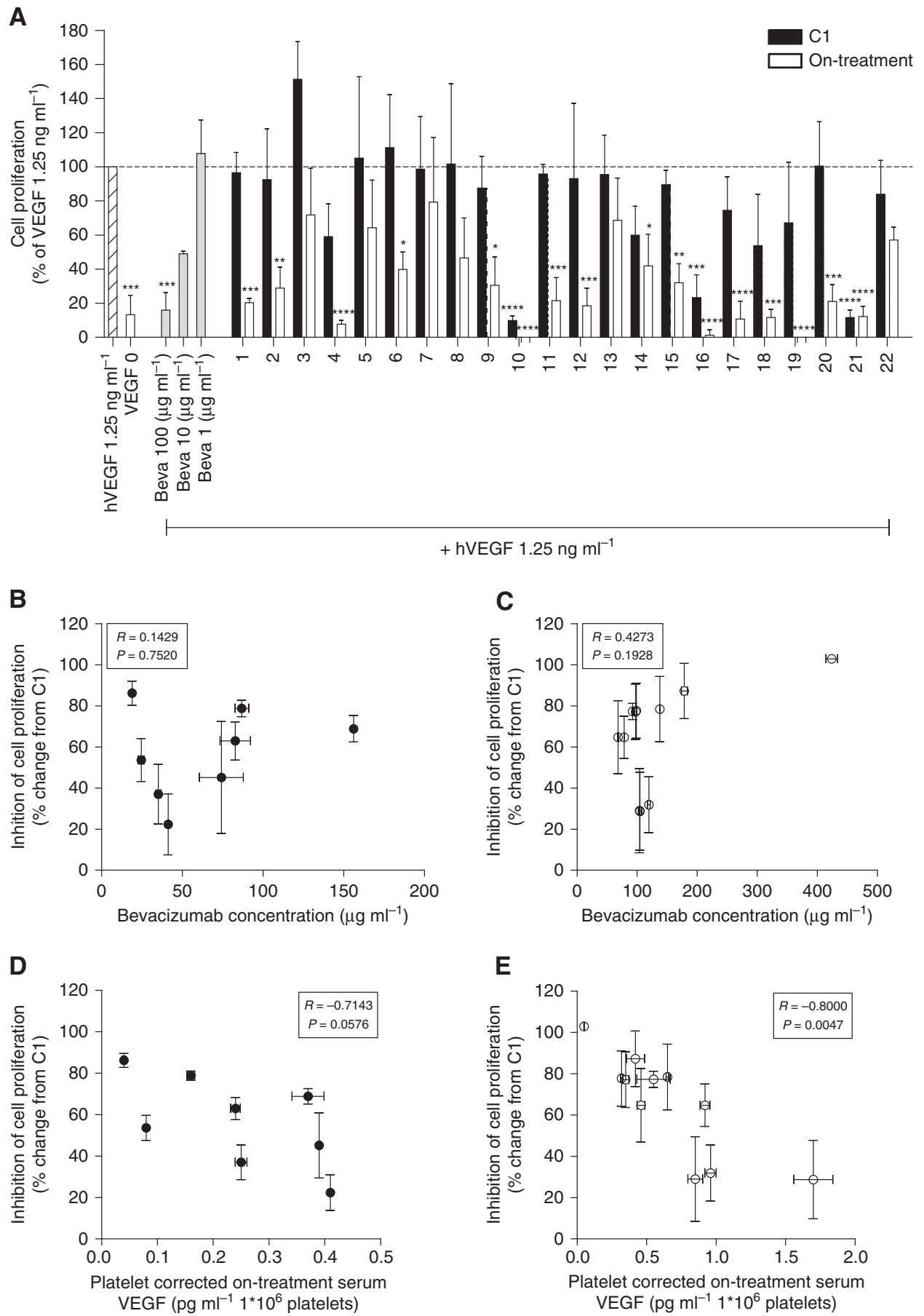

Figure 3. Effect on Ba/F3-VEGFR2 cell proliferation when hVEGF is added together with pre-treatment (C1) or on-bevacizumab treatment serum. Effect on Ba/F3-VEGFR2 cell proliferation when pre-treatment patients' serum or on-bevacizumab treatment serum (in $1: 20$ dilution) is co-incubated with hVEGF $\left(1.25 \mathrm{ng} \mathrm{ml}^{-1}\right)$. Cell proliferation is quantified relatively to hVEGF $1.25 \mathrm{ng} \mathrm{ml}^{-1}$. Cell proliferation is quantified relative to hVEGF $1.25 \mathrm{ng} \mathrm{ml}^{-1}$. Patient samples 10, 16 and 21 were excluded for further analyses because of the inhibitory effects observed with pre-treatment serum. Data is shown as mean \pm s.d. of three independent experiments. ${ }^{\star} P<0.05,{ }^{\star \star} P<0.01,{ }^{\star \star \star} P<0.001,{ }^{\star \star \star \star} P<0.0001(\mathrm{~A})$. Correlation plot of bevacizumab concentration vs the inhibition of Ba/F3-VEGFR2 cell proliferation. Data points are the mean values \pm s.d. of three independent experiments (B for patients 1-8; C for patients 9-22). Correlation plot of platelet corrected on-treatment $h V E G F$ concentration vs the inhibition of Ba/F3-VEGFR2 cell proliferation. Data points are the mean values \pm s.d. of three independent experiments ( $D$ for patients $1-8$; E for patients 9-22). 


\section{DISCUSSION}

A reproducible VEGF-dependent cell proliferation bioassay was established. Serum collected during bevacizumab therapy could be used in a dilution of $1: 20$ (5\%) to measure VEGF-dependent cell growth inhibition. Serum samples of bevacizumab-treated patients inhibited the cell proliferation compared with their pre-treatment controls to a variable extent (22-103\% inhibition). Inhibition was independent of bevacizumab concentrations in the patient's serum samples, whereas on-treatment serum hVEGF levels were correlated with $\mathrm{Ba} / \mathrm{F} 3$-VEGFR2 cell proliferation. These findings indicate that indeed during anti-VEGF therapy, such as bevacizumab, a new equilibrium emerges between free VEGF, bevacizumab and VEGFR2 and either bound VEGF to bevacizumab and bound VEGF to cellular or free circulating VEGFRs. This is further supported by the finding that inhibition of cell proliferation using on-treatment serum (compared with C1 serum) of 100\% was uncommon in patients. Because of other factors present in blood that possibly interfere in VEGF-bevacizumab or VEGF-VEGFR2 binding, similar doses of bevacizumab might lead to variable VEGF neutralisation in different patients, as a consequence of the levels of these interfering factors. Although complete VEGF neutralisation is most likely required for optimal anti-VEGF treatment efficacy, these results imply that in patients in whom there is no $100 \%$ inhibition, the dosing or frequency of bevacizumab should be altered to maximise VEGF blockade and thereby to improve its efficacy. Formal clinical evaluation of the optimal dosing of anti-VEGF therapy by using the Ba/F3-VEGFR2 bioassay is of importance to determine whether this treatment strategy can be individualised to further improve its benefit.

As indicated above, the clinical benefit of bevacizumab treatment in patients with advanced solid tumours is difficult to predict, because (1) bevacizumab is usually given in combination therapy and (2), the overall benefit is limited in most tumour types. In mCRC an improvement of 1.4 to 4.4 months in progression-free survival (PFS) was achieved (Hurwitz et al, 2004; Kabbinavar et al, 2005; Saltz et al, 2008; Tebbutt et al, 2010), whereas in only one randomised trial a statistically significant increase in overall survival (OS) of 4.7 months was shown (Hurwitz et al, 2004). In non-small cell lung cancer (NSCLC) an increase of 0.4 to 1.7 months in PFS was found (Sandler et al, 2006; Reck et al, 2009), whereas only one phase III randomised trial reported a significant increase of 2.0 months in OS (Sandler et al, 2006). Because of this minimal clinical benefit it would be important to define biomarkers that can identify those patients who are likely to respond to this treatment. Until now, no such predictive marker has been established. Circulating biomarkers with putative predictive value of these anti-VEGF therapeutics that are under evaluation include VEGF polymorphisms (Lambrechts et al, 2012), plasma neuropilin-1 (Van et al, 2012) and VEGF downstream markers like Esm1, Prnd and Aplnr (Brauer et al, 2013).

There are no prior studies reported on the use of $\mathrm{Ba} / \mathrm{F} 3$ VEGFR2 cells as a bioassay for anti-VEGF agents. Ishikawa et al (2000) have employed $\mathrm{Ba} / \mathrm{F} 3$ cells transfected with human growth hormone receptor (Ba/F3-hGFR) in order to measure the bioactivity of growth hormone in serum of people with short stature related to growth hormone bioactivity. They found that this proliferation assay is both suitable and sensitive enough to serve as bioassay for human growth hormone. In a later study by Pagani et al (2010), it was reported that the Ba/F3-hGFR bioassay might only be sensitive enough to detect extreme cases of growth hormone bioactivity (Pagani et al, 2010). Recently, another group has shown that the $\mathrm{Ba} / \mathrm{F} 3$-hGFR bioassay can also be used to detect anti-human growth hormone neutralising antibodies in human serum (Zou et al, 2013). Similar to the findings by Pagani et al (2010) for growth hormone bioactivity, the Ba/F3-VEGFR2 cell proliferation assay is not sensitive enough for detecting bioactivity of endogenous VEGF present in human serum when used in $1: 20$ dilutions. However, serum diluted to a lesser extent $(1: 10$ or lower) seemed to a variable extent toxic to the cells (data not shown) and was therefore not further used in our evaluation of the bioassay.

In three patients ( $\mathrm{nr} \mathrm{10,16}$ and 21) the use of pre-treatment serum already markedly reduced the cell proliferation compared with hVEGF $1.25 \mathrm{ng} \mathrm{ml}^{-1}$. We observed that the VEGF-dependent cell proliferation inhibition of $\mathrm{Ba} / \mathrm{F} 3-\mathrm{VEGFR} 2$ cells did not correlate with the bevacizumab concentration as measured by ELISA. Although serum was used in a dilution of $1: 20$, there should still remain ample bevacizumab to effectively neutralise hVEGF. A possible reason for the observed inhibition of cell proliferation with the addition of pre-treatment sera of patients 10,16 and 21 could be the presence of other factors in blood that interfere with the binding of VEGF to VEGFR2. Similarly, this could also be an explanation for the lack of correlation between the bevacizumab concentrations and inhibition of cell proliferation when co-incubated with on-treatment sera. In addition, other factors present in blood might cause differences in binding affinity and/or the VEGF neutralising ability of bevacizumab. This is also indicated by the fact that the bevacizumab concentrations did not correlate with the hVEGF concentrations measured at the same time point (data not shown). Factors that could have a role include changes in $\mathrm{pH}$ (Bee et al, 2013) and the presence of serum proteins, like alpha-2-macroglobulin (Soker et al, 1993; Bhattacharjee et al, 2000). Another possible explanation for this observation is the presence of soluble VEGFR-1 in serum, a protein that is able to compete for the binding of VEGF to membrane bound VEGFR2 (Duda et al, 2010; Wu et al, 2010). Third, the lack of patients' sera heat-inactivation could potentially lead to complement activation due to the presence of antibodies against antigens expressed on $\mathrm{Ba} / \mathrm{F} 3-\mathrm{VEGFR} 2$ cells and consequent cell lysis. However, heatinactivation can also result in adverse effects, like protein denaturation and aggregation of immunoglobulins (Soltis et al, 1979).

Other VEGF family members capable of binding to VEGFR2 (VEGF-C and VEGF-D) are still able to do so during bevacizumab treatment, since bevacizumab does not neutralise these factors (Yu et al, 2010). Vascular endothelial growth factor-C as well as VEGF-D have been described as possible bypass resistance mechanism of bevacizumab therapy (Lieu et al, 2013). These data suggest that VEGF-C and VEGF-D can still promote $\mathrm{Ba} / \mathrm{F} 3-\mathrm{VEGFR} 2$ cell proliferation during bevacizumab therapy, resulting in less inhibition of cell proliferation compared with pretreatment. Although these factors possibly interfere with the $\mathrm{Ba} /$ F3-VEGFR2 cell proliferation and complicate the outcome of the bioassay, this better mimics the in vivo situation as opposed to conventional ELISA and we therefore suggest that the bioassay could serve as a more reliable biomarker for anti-VEGF therapy response in patients with cancer.

The clinical monitoring utility of this bioassay may also be of value when the endogenous formation of anti-VEGF antibodies is stimulated by a vaccination treatment against VEGF (Gavilondo et al, 2014). Currently, we are conducting a phase I clinical trial to assess the VEGF-neutralising capacities of antibodies induced by a therapeutic vaccine targeting hVEGF (NCT02237638). Through active immunisation, it is expected that a polyclonal antibody response against hVEGF will be induced with VEGF-neutralising activity. In this trial the Ba/F3-VEGFR2 bioassay is being evaluated to measure the bioactivity of circulating VEGF when polyclonal anti-VEGF antibodies are being generated, which are supposed to neutralise VEGF.

In summary we have shown that the Ba/F3-VEGFR2 cell proliferation assay can be used to reproducibly determine the efficacy of bevacizumab in neutralising the biological activity of VEGF both in vitro and in patient-derived serum samples before 
and during treatment with bevacizumab. The interaction of VEGF with its receptors occurs at the interface of (endothelial) cells and blood, which is mimicked in the Ba/F3-VEGFR2 bioassay. Therefore, we propose that the bioassay more accurately reflects the availability of VEGF for binding to its receptor as it occurs in patients compared with conventional ELISA. Accordingly we hypothesise that the degree of functional VEGF neutralisation as measured by the Ba/F3-R2 cell proliferation assay correlates with the VEGF neutralising ability of bevacizumab and possibly other agents that target VEGF. Especially in the situation where bevacizumab is not given in combination with chemotherapy (i.e., glioblastoma or renal cell carcinoma) this could be associated with clinical response and/or survival. To investigate this hypothesis, a follow-up study should investigate this bioassay in a larger patient cohort with clinical response data.

\section{ACKNOWLEDGEMENTS}

This project was supported by Immunovo BV. We thank K. Alitalo for providing the $\mathrm{Ba} / \mathrm{F} 3-\mathrm{VEGFR} 2$ cells.

\section{CONFLICT OF INTEREST}

The authors declare no conflict of interest.

\section{REFERENCES}

Baar J, Silverman P, Lyons J, Fu P, Abdul-Karim F, Ziats N, Wasman J, Hartman P, Jesberger J, Dumadag L, Hohler E, Leeming R, Shenk R, Chen H, McCrae K, Dowlati A, Remick SC, Overmoyer B (2009) A vasculature-targeting regimen of preoperative docetaxel with or without bevacizumab for locally advanced breast cancer: impact on angiogenic biomarkers. Clin Cancer Res 15(10): 3583-3590.

Bee C, Abdiche YN, Pons J, Rajpal A (2013) Determining the binding affinity of therapeutic monoclonal antibodies towards their native unpurified antigens in human serum. PLoS One 8(11): e80501.

Bhattacharjee G, Asplin IR, Wu SM, Gawdi G, Pizzo SV (2000) The conformation-dependent interaction of alpha 2-macroglobulin with vascular endothelial growth factor. A novel mechanism of alpha 2-macroglobulin/growth factor binding. J Biol Chem 275(35): 26806-26811.

Brauer MJ, Zhuang G, Schmidt M, Yao J, Wu X, Kaminker JS, Jurinka SS, Kolumam G, Chung AS, Jubb A, Modrusan Z, Ozawa T, James CD, Phillips H, Haley B, Tam RN, Clermont AC, Cheng JH, Yang SX, Swain SM, Chen D, Scherer SJ, Koeppen H, Yeh RF, Yue P, Stephan JP, Hegde P, Ferrara N, Singh M, Bais C (2013) Identification and analysis of in vivo VEGF downstream markers link VEGF pathway activity with efficacy of anti-VEGF therapies. Clin Cancer Res 19(13): 3681-3692.

Brookes K, Cummings J, Backen A, Greystoke A, Ward T, Jayson GC, Dive C (2010) Issues on fit-for-purpose validation of a panel of ELISAs for application as biomarkers in clinical trials of anti-angiogenic drugs. $\mathrm{Br} \mathrm{J}$ Cancer 102(10): 1524-1532.

Del VM, Mortarini R, Canova S, Di GL, Pimpinelli N, Sertoli MR, Bedognetti D, Queirolo P, Morosini P, Perrone T, Bajetta E, Anichini A (2010) Bevacizumab plus fotemustine as first-line treatment in metastatic melanoma patients: clinical activity and modulation of angiogenesis and lymphangiogenesis factors. Clin Cancer Res 16(23): 5862-5872.

Dong J, Grunstein J, Tejada M, Peale F, Frantz G, Liang WC, Bai W, Yu L, Kowalski J, Liang X, Fuh G, Gerber HP, Ferrara N (2004) VEGF-null cells require PDGFR alpha signaling-mediated stromal fibroblast recruitment for tumorigenesis. EMBO J 23(14): 2800-2810.

Duda DG, Willett CG, Ancukiewicz M, di TE, Shah M, Czito BG, Bentley R, Poleski M, Lauwers GY, Carroll M, Tyler D, Mantyh C, Shellito P, Clark JW, Jain RK (2010) Plasma soluble VEGFR-1 is a potential dual biomarker of response and toxicity for bevacizumab with chemoradiation in locally advanced rectal cancer. Oncologist 15(6): 577-583.
Ferrara N, Adamis AP (2016) Ten years of anti-vascular endothelial growth factor therapy. Nat Rev Drug Discov 15(6): 385-403.

Finley SD, Engel-Stefanini MO, Imoukhuede PI, Popel AS (2011) Pharmacokinetics and pharmacodynamics of VEGF-neutralizing antibodies. BMC Syst Biol 5: 193.

Finley SD, Popel AS (2013) Effect of tumour microenvironment on tumor VEGF during anti-VEGF treatment: systems biology predictions. J Natl Cancer Inst 105(11): 802-811.

Gavilondo JV, Hernandez-Bernal F, Ayala-Avila M, de la Torre AV, de la Torre J, Morera-Diaz Y, Bequet-Romero M, Sanchez J, Valenzuela CM, Martin Y, Selman-Housein KH, Garabito A, Lazo OC (2014) Specific active immunotherapy with a VEGF vaccine in patients with advanced solid tumors. results of the CENTAURO antigen dose escalation phase I clinical trial. Vaccine 32(19): 2241-2250.

George ML, Eccles SA, Tutton MG, Abulafi AM, Swift RI (2000) Correlation of plasma and serum vascular endothelial growth factor levels with platelet count in colorectal cancer: clinical evidence of platelet scavenging? Clin Cancer Res 6(8): 3147-3152.

Giatromanolaki A, Koukourakis MI, Sivridis E, Gatter KC, Trarbach T, Folprecht G, Shi MM, Lebwohl D, Jalava T, Laurent D, Meinhardt G, Harris AL (2012) Vascular density analysis in colorectal cancer patients treated with vatalanib (PTK787/ZK222584) in the randomised CONFIRM trials. Br J Cancer 107(7): 1044-1050.

Guo J, Glass JO, McCarville MB, Shulkin BL, Daryani VM, Stewart CF, Wu J, Mao S, Dwek JR, Fayad LM, Madewell JE, Navid F, Daw NC, Reddick WE (2015) Assessing vascular effects of adding bevacizumab to neoadjuvant chemotherapy in osteosarcoma using DCE-MRI. Br J Cancer 113(9): $1282-1288$.

Hayashi H, Arao T, Matsumoto K, Kimura H, Togashi Y, Hirashima Y, Horita Y, Iwasa S, Okita NT, Honma Y, Takashima A, Kato K, Hamaguchi T, Shimada Y, Nakagawa K, Nishio K, Yamada Y (2014) Biomarkers of reactive resistance and early disease progression during chemotherapy plus bevacizumab treatment for colorectal carcinoma. Oncotarget 5(9): 2588-2595.

Hegde PS, Jubb AM, Chen D, Li NF, Meng YG, Bernaards C, Elliott R, Scherer SJ, Chen DS (2013) Predictive impact of circulating vascular endothelial growth factor in four phase III trials evaluating bevacizumab. Clin Cancer Res 19(4): 929-937.

Hsei V, Deguzman GG, Nixon A, Gaudreault J (2002) Complexation of VEGF with bevacizumab decreases VEGF clearance in rats. Pharm Res 19(11): 1753-1756

Hurwitz H, Fehrenbacher L, Novotny W, Cartwright T, Hainsworth J, Heim W, Berlin J, Baron A, Griffing S, Holmgren E, Ferrara N, Fyfe G, Rogers B, Ross R, Kabbinavar F (2004) Bevacizumab plus irinotecan, fluorouracil, and leucovorin for metastatic colorectal cancer. N Engl J Med 350(23): 2335-2342.

Ishikawa M, Nimura A, Horikawa R, Katsumata N, Arisaka O, Wada M, Honjo M, Tanaka T (2000) A novel specific bioassay for serum human growth hormone. J Clin Endocrinol Metab 85(11): 4274-4279.

Jayson GC, Kerbel R, Ellis LM, Harris AL (2016) Antiangiogenic therapy in oncology: current status and future directions. Lancet 388(10043): 518-529.

Kabbinavar FF, Schulz J, McCleod M, Patel T, Hamm JT, Hecht JR, Mass R, Perrou B, Nelson B, Novotny WF (2005) Addition of bevacizumab to bolus fluorouracil and leucovorin in first-line metastatic colorectal cancer: results of a randomized phase II trial. J Clin Oncol 23(16): 3697-3705.

Kut C, Mac GF, Popel AS (2007) Where is VEGF in the body? A meta-analysis of VEGF distribution in cancer. Br J Cancer 97(7): 978-985.

Lam SW, de Groot SM, Honkoop AH, Jager A, ten Tije AJ, Bos MM, Linn SC, van den Bosch J, Kroep JR, Braun JJ, van TH, Boven E (2014) Paclitaxel and bevacizumab with or without capecitabine as first-line treatment for HER2-negative locally recurrent or metastatic breast cancer: a multicentre, open-label, randomised phase 2 trial. Eur J Cancer 50(18): 3077-3088.

Lambrechts D, Claes B, Delmar P, Reumers J, Mazzone M, Yesilyurt BT, Devlieger R, Verslype C, Tejpar S, Wildiers H, de HS, Carmeliet P, Scherer SJ, Van CE (2012) VEGF pathway genetic variants as biomarkers of treatment outcome with bevacizumab: an analysis of data from the AViTA and AVOREN randomised trials. Lancet Oncol 13(7): 724-733.

Lieu CH, Tran H, Jiang ZQ, Mao M, Overman MJ, Lin E, Eng C, Morris J, Ellis L, Heymach JV, Kopetz S (2013) The association of alternate VEGF ligands with resistance to anti-VEGF therapy in metastatic colorectal cancer. PLoS One 8(10): e77117. 
Loupakis F, Cremolini C, Fioravanti A, Orlandi P, Salvatore L, Masi G, Di DT, Canu B, Schirripa M, Frumento P, Di PA, Danesi R, Falcone A, Bocci G (2011) Pharmacodynamic and pharmacogenetic angiogenesis-related markers of first-line FOLFOXIRI plus bevacizumab schedule in metastatic colorectal cancer. Br J Cancer 104(8): 1262-1269.

Makinen T, Veikkola T, Mustjoki S, Karpanen T, Catimel B, Nice EC, Wise L, Mercer A, Kowalski H, Kerjaschki D, Stacker SA, Achen MG, Alitalo K (2001) Isolated lymphatic endothelial cells transduce growth, survival and migratory signals via the VEGF-C/D receptor VEGFR-3. EMBO J 20(17): 4762-4773.

Mehta S, Hughes NP, Buffa FM, Li SP, Adams RF, Adwani A, Taylor NJ, Levitt NC, Padhani AR, Makris A, Harris AL (2011) Assessing early therapeutic response to bevacizumab in primary breast cancer using magnetic resonance imaging and gene expression profiles. J Natl Cancer Inst Monogr 2011(43): 71-74.

Nagengast WB, Hooge MN, van Straten EM, Kruijff S, Brouwers AH, den Dunnen WF, de Jong JR, Hollema H, Dierckx RA, Mulder NH, de Vries EG, Hoekstra HJ, Hospers GA (2011) VEGF-SPECT with ${ }^{111}$ In-bevacizumab in stage III/IV melanoma patients. Eur J Cancer 47(10): 1595-1602.

Nakaya A, Kurata T, Yokoi T, Iwamoto S, Torii Y, Katashiba Y, Ogata M, Hamada M, Kon M, Nomura S (2016) Retrospective analysis of bevacizumab-induced hypertension and clinical outcome in patients with colorectal cancer and lung cancer. Cancer Med 5(7): 1381-1387.

Niers TM, Richel DJ, Meijers JC, Schlingemann RO (2011) Vascular endothelial growth factor in the circulation in cancer patients may not be a relevant biomarker. PLoS One 6(5): e19873.

Oosting SF, Brouwers AH, van Es SC, Nagengast WB, Oude Munnink TH, Lub-de Hooge MN, Hollema H, de Jong JR, de Jong IJ, de HS, Scherer SJ, Sluiter WJ, Dierckx RA, Bongaerts AH, Gietema JA, de Vries EG (2015) 89 Zr-bevacizumab PET visualizes heterogeneous tracer accumulation in tumor lesions of renal cell carcinoma patients and differential effects of antiangiogenic treatment. J Nucl Med 56(1): 63-69.

Pagani S, Chaler EA, Meazza C, Maceiras M, Gonzalez ME, Rivarola MA, Cantoni F, Travaglino P, Della CL, Laarej K, Bozzola M, Belgorosky A (2010) Is BaF3 bioassay useful to identify patients with bioinactive growth hormone? J Pediatr Endocrinol Metab 23(8): 783-788.

Peterson JE, Zurakowski D, Italiano Jr. JE, Michel LV, Connors S, Oenick M, D'Amato RJ, Klement GL, Folkman J (2012) VEGF, PF4 and PDGF are elevated in platelets of colorectal cancer patients. Angiogenesis 15(2): 265-273.

Pinedo HM, Verheul HM, D'Amato RJ, Folkman J (1998) Involvement of platelets in tumor angiogenesis? Lancet 352(9142): 1775-1777.

Pommier AJ, Shaw R, Spencer SK, Morgan SR, Hoff PM, Robertson JD, Barry ST, Jurgensmeier JM (2014) Serum protein profiling reveals baseline and pharmacodynamic biomarker signatures associated with clinical outcome in mCRC patients treated with chemotherapy $+/$ - cediranib. Br J Cancer 111(8): 1590-1604.

Reck M, von PJ, Zatloukal P, Ramlau R, Gorbounova V, Hirsh V, Leighl N, Mezger J, Archer V, Moore N, Manegold C (2009) Phase III trial of cisplatin plus gemcitabine with either placebo or bevacizumab as first-line therapy for nonsquamous non-small-cell lung cancer: AVAil. J Clin Oncol 27(8): $1227-1234$

Saltz LB, Clarke S, Diaz-Rubio E, Scheithauer W, Figer A, Wong R, Koski S, Lichinitser M, Yang TS, Rivera F, Couture F, Sirzen F, Cassidy J (2008) Bevacizumab in combination with oxaliplatin-based chemotherapy as first-line therapy in metastatic colorectal cancer: a randomized phase III study. J Clin Oncol 26(12): 2013-2019.

Sandler A, Gray R, Perry MC, Brahmer J, Schiller JH, Dowlati A, Lilenbaum R, Johnson DH (2006) Paclitaxel-carboplatin alone or with bevacizumab for non-small-cell lung cancer. N Engl J Med 355(24): 2542-2550.

Soker S, Svahn CM, Neufeld G (1993) Vascular endothelial growth factor is inactivated by binding to alpha 2 -macroglobulin and the binding is inhibited by heparin. J Biol Chem 268(11): 7685-7691.
Soltis RD, Hasz D, Morris MJ, Wilson ID (1979) The effect of heat inactivation of serum on aggregation of immunoglobulins. Immunology 36(1): 37-45.

Stacker SA, Vitali A, Caesar C, Domagala T, Groenen LC, Nice E, Achen MG, Wilks AF (1999) A mutant form of vascular endothelial growth factor (VEGF) that lacks VEGF receptor-2 activation retains the ability to induce vascular permeability. J Biol Chem 274(49): 34884-34892.

Stefanini MO, Wu FT, Mac GF, Popel AS (2010) Increase of plasma VEGF after intravenous administration of bevacizumab is predicted by a pharmacokinetic model. Cancer Res 70(23): 9886-9894.

Tebbutt NC, Wilson K, Gebski VJ, Cummins MM, Zannino D, Van Hazel GA, Robinson B, Broad A, Ganju V, Ackland SP, Forgeson G, Cunningham D, Saunders MP, Stockler MR, Chua Y, Zalcberg JR, Simes RJ, Price TJ (2010) Capecitabine, bevacizumab, and mitomycin in first-line treatment of metastatic colorectal cancer: results of the Australasian Gastrointestinal Trials Group Randomized Phase III MAX Study. J Clin Oncol 28(19): 3191-3198.

Van CE, de HS, Kang YK, Ohtsu A, Tebbutt NC, Ming XJ, Peng YW, Langer B, Delmar P, Scherer SJ, Shah MA (2012) Bevacizumab in combination with chemotherapy as first-line therapy in advanced gastric cancer: a biomarker evaluation from the AVAGAST randomized phase III trial. J Clin Oncol 30(17): 2119-2127.

Verheul HM, Hoekman K, Luykx-de BS, Eekman CA, Folman CC, Broxterman HJ, Pinedo HM (1997) Platelet: transporter of vascular endothelial growth factor. Clin Cancer Res 3(12 Pt 1): 2187-2190.

Verheul HM, Lolkema MP, Qian DZ, Hilkes YH, Liapi E, Akkerman JW, Pili R, Voest EE (2007) Platelets take up the monoclonal antibody bevacizumab. Clin Cancer Res 13(18 Pt 1): 5341-5347.

Verheul HM, Paesante S, Jaspers J, Hammers H, Salumbides B, Pili R (2008) VEGF pharmacodynamics during bevacizumab treatment. J Clin Oncol 26(15): suppl 14633 (ASCO annual meeting abstracts) Ref Type: Conference Proceeding.

Verheul HM, Pinedo HM (2007) Possible molecular mechanisms involved in the toxicity of angiogenesis inhibition. Nat Rev Cancer 7(6): 475-485.

Webb NJ, Bottomley MJ, Watson CJ, Brenchley PE (1998) Vascular endothelial growth factor (VEGF) is released from platelets during blood clotting: implications for measurement of circulating VEGF levels in clinical disease. Clin Sci (Lond) 94(4): 395-404.

Willett CG, Duda DG, di TE, Boucher Y, Ancukiewicz M, Sahani DV, Lahdenranta J, Chung DC, Fischman AJ, Lauwers GY, Shellito P, Czito BG, Wong TZ, Paulson E, Poleski M, Vujaskovic Z, Bentley R, Chen HX, Clark JW, Jain RK (2009) Efficacy, safety, and biomarkers of neoadjuvant bevacizumab, radiation therapy, and fluorouracil in rectal cancer: a multidisciplinary phase II study. J Clin Oncol 27(18): 3020-3026.

Wu FT, Stefanini MO, Mac GF, Kontos CD, Annex BH, Popel AS (2010) A systems biology perspective on sVEGFR1: its biological function, pathogenic role and therapeutic use. J Cell Mol Med 14(3): 528-552.

Yu Y, Lee P, Ke Y, Zhang Y, Yu Q, Lee J, Li M, Song J, Chen J, Dai J, Do Couto FJ, An Z, Zhu W, Yu GL (2010) A humanized anti-VEGF rabbit monoclonal antibody inhibits angiogenesis and blocks tumor growth in xenograft models. PLoS One 5(2): e9072.

Zou L, vonKerczek A, Bukreyeva N, Kaufman T, Klang J, Pukac L, Rasamoelisolo M, Sadhu C, Liu P (2013) Development of a Bioassay for the Detection of Anti-human Growth Hormone Neutralizing Antibodies using hGHR-expressing BA/F3 Cells. 2013 AAPS Annual Meeting and Exposition. 2013. Ref Type: Conference Proceeding.

This work is published under the standard license to publish agreement. After 12 months the work will become freely available and the license terms will switch to a Creative Commons AttributionNonCommercial-Share Alike 4.0 Unported License. 